\title{
Penjadwalan Job Shop Dengan Pendekatan Algoritma Artificial Immune System
}

\author{
Riven Nasution*, Annisa Kesy Garside, Dana Marsetiya Utama \\ Jurusan Teknik Industri, Fakultas Teknik, Universitas Muhammadiyah Malang \\ Jl. Raya Tlogomas No.246 Malang, Jawa Timur, Phone: +62 341464 318, Fax: +62 341460435 \\ *Surel: rivennasution@gmail.com
}

\begin{abstract}
Production scheduling is an important activity in manufacturing. Optimal scheduling affects the time of completion of the work. PT. Interpack is a company that produces packaging machines. The job schedule of the product spare part still uses the random priority rules. Use of random rules makes a lot of time delay. Delay causes operator and machine idle. Delay also causes the total time of completion of the work (makespan) and delay the greater. So it needs to be rescheduled to work on the spare part of product. Job scheduling using the Artificial Immune System (AIS) algorithm. AIS was developed by Farmer et al. The AIS algorithm refers to the human immune system. The stages of the AIS algorithm begin with random initialization, antibody representation and gene classification, clone breeding, selection of donor antibodies, germ-line construction, gene fragment redesign, and ending with diversification of antibodies. AIS algorithm scheduling resulted in a more optimal new schedule. AIS algorithm scheduling generates a future of 6483.91 minutes. Company scheduling generates makespan of 7059.99 minutes. AIS Schedule finishes algorithm 4 days of the due date. AIS algorithm schedule increase machine utility by $1 \%$.
\end{abstract}

Keywords: artificial immune system, job shop, schedulling

\begin{abstract}
Abstrak
Penjadwalan produksi merupakan aktivitas penting di manufaktur. Penjadwalan yang optimal mempengaruhi waktu penyelesaian pekerjaan. PT. Interpack merupakan perusahaan yang memproduksi mesin pengemas. Jadwal pengerjaan spare part produk masih menggunakan aturan prioritas random. Penggunan aturan random membuat banyak waktu delay. Delay menyebabkan operator dan mesin menganggur. Delay juga menyebabkan total waktu penyelesaian pekerjaan (makespan) dan keterlambatan semakin besar. Sehingga perlu dilakukan penjadwalan ulang untuk pengerjaan spare part produk. Penjadwalan usulan menggunakan algoritma Artificial Immune System (AIS). AIS dikembangkan oleh Farmer dan kawan-kawan. Algoritma AIS mengacu pada sistem kekebalan tubuh manusia. Tahapan algoritma AIS dimulai dengan inisialisasi acak, representasi antibodi dan klasifikasi gen, pengembangbiakan clone, seleksi antibodi-antibodi donor, konstruksi germ-line, pengaturan ulang fragmen gen, dan diakhiri dengan diversifikasi antibodi. Penjadwalan algoritma AIS menghasilkan jadwal baru yang lebih optimal. Penjadwalan algoritma AIS menghasilkan makespan sebesar 6483,91 menit. Penjadwalan perusahan menghasilkan makespan sebesar 7059,99 menit. Jadwal algoritma AIS menyelesaikan lebih cepat 4 hari dari due date dan mampu meningkatkan utilitas mesin sebesar $1 \%$.
\end{abstract}

Kata kunci: artificial immune system, job shop, penjadwalan

\section{Pendahuluan}

Penjadwalan adalah kegiatan pengalokasian sumber-sumber atau mesin-mesin yang ada untuk menjalankan sekumpulan tugas dalam jangka waktu tertentu [1]. Penjadwalan juga bisa diartikan proses pengurutan pembuatan produk secara menyeluruh pada beberapa mesin [2]. Penjadwalan yang terperinci akan memerlukan 
informasi yang lebih banyak daripada tipe informasi yang diperlukan untuk membuat rencana produksi [3]. Hal ini perlu untuk mengetahui kemampuan dari setiap mesin, setiap pengikat, setiap operator, setiap departemen, dan lain-lain. Dengan demikian masalah sequencing senantiasa melibatkan pengerjaan sejumlah komponen yang sering disebut dengan istilah 'job'. Job sendiri masih merupakan komposisi dari sejumlah elemen-elemen dasar yang disebut aktivitas atau operasi.

Menyusun semua operasi dari semua job yang memiliki pola aliran berbeda-beda pada tiap mesin, sehingga keseluruhan job dapat diproses menurut urutan pengerjaannya merupakan masalah dari penjadwalan job shop [4]. Pada penjadwalan produksi terdapat beberapa kriteria performa, salah satunya adalah minimalisasi makespan. Makespan adalah total waktu proses yang dibutuhkan untuk menyelesaikan kumpulan tugas (job). Meminimasi makespan, dimaksudkan untuk meraih utilisasi yang tinggi dari peralatan dan sumber daya dengan cara menyelesaikan job secepatnya [5-7].

PT. Interpack Packaging and Processing Manufacturers merupakan perusahaan manufaktur yang memproduksi mesin pengemasan produk (packaging machine) dengan aliran job shop. Produk yang dihasilkan berbagai macam tipe, sesuai dengan jenis produk yang akan dikemas. Perusahaan ini bertipe produksi make to order dan make to stock. Make to order, perusahaan dapat melayani pembuatan mesin sesuai permintaan dan jenis produk. Make to stock, perusahaan selalu membuat persediaan yang disesuaikan permintaan pasar pada periode berikutnya. Perusahaan memiliki fasilitas kerja yang lengkap dan dapat memproduksi part sendiri (make) untuk komponenkomponen perakitannya.

Berdasarkan pengamatan yang telah dilakukan di PT. Interpack Packaging and Processing Manufacturers. Jadwal pengerjaan spare part produk masih dilakukan dengan sistem aturan prioritas random (setiap pekerjaan yang akan dikerjakan diurutkan secara acak), sehingga urutan pengerjaan produk yang sama dengan pemesanan berbeda memiliki urutan pengerjaan yang berbeda. Sedangkan untuk memproduksi ada yang membutuhkan waktu lama untuk setiap prosesnya dan ada yang membutuhkan waktu singkat untuk tiap prosesnya, sehingga akan membuat banyak waktu delay yang akan menyebabkan operator dan mesin menganggur serta memperlama total waktu penyelesaian pekerjaan (makespan) dan terlambatnya penyelesaian spare part.

Dari permasalahan tersebut, perlu dilakukan penjadwalan produksi untuk pengerjaan spare part produk. Produk dijadwalkan menggunakan algoritma Artificial Immune System (AIS), seperti penelitian terdahulu yang dilakukan oleh Astuti yang menggunakan algoritma ini untuk meminimalkan waktu keseluruhan (makespan) [8]. Imunologi adalah ilmu baru yang asal-usulnya dikaitkan dengan Edward Jenner pada tahun 1796, lalu pada tahun 1986 artificial immune system (AIS) dikembangkan oleh Farmer dan kawan-kawan, yang terinspirasi oleh sistem kekebalan tubuh manusia [9]. Algoritma AIS meniru perilaku dan sifat sel-sel kekebalan, khususnya sel B, sel T, dan antigen. Sama dengan sistem kekebalan biologis algoritma immune memiliki kapabilitas pencarian solusi optimal dengan memelihara level tinggi diversitas pada ruang pencarian. Pada masalah optimasi, antigen $\left(A_{g k}\right)$ dan antibodi $\left(A_{b}\right)$ bekerja sebagai tujuan $(f)$ dan solusi yang terkait $(x)$ pada model komputasi, dan diekspresikan sebagai berikut [10]. Kelebihan algoritma AIS dibandingkan algoritma lain adalah penggunaan populasi, seleksi dan mutasi sehingga bisa bekerja secara paralel untuk banyak solusi sekaligus dan tidak memerlukan banyak parameter yang diperlukan. Metode AIS diharapkan dapat meminimalisasi makespan pembuatan spare part mesin dan meningkatkan utilitas mesin produksi. 


\section{Metodologi}

Dalam penjadwalan job shop menggunakan algoritma AIS ada tujuh langkah, langkah-langkah tersebut adalah sebagai berikut [9]:

Tahap 1. Initialisasi acak dari populasi antibodi

Serupa dengan algoritma-algoritma genetik yang digunakan di dalam job shop scheduling problem, rangkaian integer awal yang menyandikan populasi antibodi dihasilkan secara acak yang melambangkan job dengan proses awal sesuai jadwal yang ada sebelumnya.

Tahap 2. Representasi antibodi dan klasifikasi gen

Untuk j pekerjaan dan m mesin, suatu antibodi berisi j x m gen. Setiap pekerjaan muncul berulang pada antibodi tersebut $\mathrm{m}$ kali, dan setiap pengulangan gen (bilangan integer) tidak mengindikasikan suatu operasi yang kongkret dari suatu pekerjaan, tetapi mengacu kepada suatu operasi yang unik.

Elemen waktu merupakan nilai yang menunjukkan total waktu pengerjaan dari semua job. Untuk penentuan rantai dilakukan dengan melihat proporsi gen rantai ringan $(\mathrm{L})$ terhadap gen rantai berat $(\mathrm{H})$.

Tahap 3. Pengembang biakan clone

Hal ini memerhatikan gen-gen ringan yang ada pada mutasi awal, karena hipermutasi hanya dapat terjadi di dalam gen-gen rantai ringan. Di mana gen rantai ringan terdapat setiap pekerjaan akhir pada mesin-mesin berbeda. Untuk itu dapat dilakukan pengembangbiakan clone yang mengambil mutasi bilangan acak di mana job pada bilangan baru memiliki job yang sama.

Tahap 4. Seleksi untuk antibodi-antibodi donor

Untuk antibodi-antibodi donor diambil beberapa sampel yang dirasa (diasumsikan) dapat menggantikan gen rantai ringan yang ada pada job sebelumnya. Semakin banyak job yang ada terhadap daftar urutan pengerjaan mesin maka semakin banyak pula donor yang bisa dihasilkan.

Tahap 5. Konstruksi germ-line

Merupakan pembentukan garis yang dianggap memenuhi asumsi dari perhitungan job yang ada. Sebagai asumsi diambil perbaikan pada job yang mengalami penggunaan mesin terbanyak. Sehingga rangkaian yang didapat adalah pembentukan antibodi baru berdasarkan donor yang diujikan.

Tahap 6. Pengaturan ulang fragmen gen

Untuk pengaturan ulang gen dilakukan berdasarkan pengaturan yang berbasiskan mesin, dengan melihat mesin mana yang memiliki delay dan memungkinkan untuk dilakukan pengaturan ulang.

Tahap 7. Diversifikasi antibodi

Pada bagian ini hanya beberapa mekanisme yang dapat diterapkan berdasarkan urutan pekerjaan terhadap mesin yang digunakan. Hal ini karena adanya job-job yang tidak dapat dilakukan mekanisme antibodi tanpa melihat urutan pengerjaan seharusnya dari pekerjaan yang telah ditetapkan. Sehingga diperlukan perhatian pada 
saat menerapkan mekanisme-mekanisme untuk mendapatkan jadwal yang diinginkan. Adapun mekanisme yang dilakukan antara lain dalam upaya meminimalisasi makespan:

a. Mutasi titik somatis

Dilakukan dengan asumsi mesin yang memiliki proses terpanjang dilakukan belakangan.

b. Rekombinasi somatis

Merupakan proses pemilihan satu atau lebih fragmen gen rantai berat dengan panjang yang sama untuk dilakukan pertukaran yang parsial diantara dua fragmen tersebut.

Setelah semua tahap penjadwalan dilakukan maka selanjutnya dilakukan perhitungan waktu lateness dan utilitas mesin.

- $\quad$ Lateness, yaitu penyimpangan waktu penyelesaian due date [1].

Lateness $=$ Completion time - Due date

Jika: $\mathrm{Li}<0$, maka saat penyelesaian job sebelum due date (early).

Pers (1)

$\mathrm{Li}=0$, maka saat penyelesaian job tepat sesuai due date.

$\mathrm{Li}>0$, maka saat penyelesaian job setelah due date (tardy).

- Utilitas mesin $\left(\mathrm{U}_{\mathrm{m}}\right)$, merupakan rasio dari seluruh waktu proses yang dibebankan pada mesin dengan rentang waktu untuk menyelesaikan seluruh tugas pada mesin tersebut [9].

$$
U_{m}=\frac{\sum_{i=1}^{n} t_{i}}{F_{\max }}
$$

Setelah semua tahap pengolahan data selesai maka tahap yang terakhir adalah melakukan perbandingan hasil dari penjadwalan tersebut.

\section{Hasil dan Pembahasan}

Data permintaan mesin packaging pada bulan Maret 2016 adalah mesin SH28R dan mesin SH38R, detail permintaan dapat dilihat pada Tabel 1. Data due date Jadwal yang dikumpulkan pada penelitian ini adalah pada bulan Maret 2016 yang dapat dilihat pada Tabel 2. waktu setiap proses dapat dilihat pada Tabel 3.

Tabel 1 Data Spare Part Mesin SH28R

\begin{tabular}{ccc}
\hline Mesin & \multicolumn{2}{c}{ Tanggal dan Jumlah Pemesanan } \\
\hline SH28R & 4 Maret (2 unit) & 18 Maret (1 unit) \\
SH38R & 11 Maret (2 unit) & \\
\hline
\end{tabular}

Tabel 2 Data Due Date Spare Permintaan

\begin{tabular}{ccccc}
\hline No & Produk & Qty & Tanggal Permintaan & Due Date Produk \\
\hline 1 & SH28R & 2 & 4 Maret & 25 Maret \\
2 & SH38R & 2 & 11 Maret & 29 Maret \\
3 & SH28R & 1 & 18 Maret & 30 Maret \\
\hline
\end{tabular}


Tabel 3 Waktu Proses

\begin{tabular}{|c|c|c|}
\hline$J o b$ & Operasi & $\begin{array}{l}\text { Waktu Proses } \\
\text { (menit) }\end{array}$ \\
\hline \multirow[t]{2}{*}{ J1 } & O1.1.2 & 40 \\
\hline & O1.2.8 & 60 \\
\hline \multirow[t]{4}{*}{ J2 } & $\mathrm{O} 2.1 .2$ & 25 \\
\hline & $\mathrm{O} 2.2 .8$ & 10 \\
\hline & O2.3.12 & 12.58 \\
\hline & $\mathrm{O} 2.4 .13$ & 21 \\
\hline \multirow[t]{6}{*}{ J3 } & O3.1.1 & 3.92 \\
\hline & O3.2.8 & 35 \\
\hline & O3.3.9 & 25 \\
\hline & O3.4.7 & 50 \\
\hline & O3.5.12 & 15.25 \\
\hline & O3.6.14 & 30 \\
\hline \multirow[t]{3}{*}{$\mathrm{J} 4$} & O4.1.1 & 2.83 \\
\hline & O4.2.5 & 14.67 \\
\hline & O4.3.8 & 10 \\
\hline \multirow[t]{2}{*}{ J5 } & O5.1.2 & 30 \\
\hline & O5.2.8 & 50 \\
\hline \multirow[t]{2}{*}{ J6 } & O6.1.2 & 10 \\
\hline & O6.2.8 & 20 \\
\hline \multirow[t]{5}{*}{$\mathrm{J} 7$} & O7.1.1 & 15.08 \\
\hline & O7.2.5 & 30.17 \\
\hline & O7.3.7 & 45 \\
\hline & O7.4.12 & 15.21 \\
\hline & O7.5.14 & 30 \\
\hline \multirow[t]{2}{*}{ J8 } & O8.1.15 & 40 \\
\hline & O8.2.6 & 30.67 \\
\hline \multirow[t]{2}{*}{ J8 } & O8.3.12 & 30 \\
\hline & O8.4.13 & 20 \\
\hline \multirow[t]{4}{*}{ J9 } & O9.1.15 & 20 \\
\hline & O9.2.6 & 15.83 \\
\hline & O9.3.12 & 15 \\
\hline & O9.4.13 & 19.67 \\
\hline \multirow[t]{5}{*}{$\mathrm{J} 10$} & O10.1.15 & 420 \\
\hline & O10.2.16 & 188.25 \\
\hline & O10.3.3 & 24.67 \\
\hline & O10.4.11 & 485.25 \\
\hline & O10.5.12 & 35.5 \\
\hline
\end{tabular}

\begin{tabular}{|c|c|c|}
\hline$J o b$ & Operasi & $\begin{array}{l}\text { Waktu roses } \\
\text { (menit) }\end{array}$ \\
\hline \multirow[t]{4}{*}{ J11 } & O11.1.4 & 49.67 \\
\hline & O11.2.3 & 5 \\
\hline & O11.3.6 & 20.5 \\
\hline & O11.4.10 & 45.33 \\
\hline \multirow[t]{2}{*}{ J12 } & O12.1.1 & 3 \\
\hline & O12.2.5 & 29.77 \\
\hline \multirow[t]{2}{*}{ J13 } & O13.1.1 & 4 \\
\hline & O13.2.5 & 30.33 \\
\hline \multirow[t]{2}{*}{ J14 } & O14.1.1 & 3.00 \\
\hline & O14.2.5 & 20.07 \\
\hline \multirow[t]{3}{*}{ J15 } & O15.1.15 & 95 \\
\hline & O15.2.6 & 29.25 \\
\hline & O15.3.3 & 15 \\
\hline \multirow[t]{2}{*}{ J15 } & O15.4.12 & 30.5 \\
\hline & O15.5.13 & 39.92 \\
\hline \multirow[t]{5}{*}{ J16 } & O16.1.1 & 10.67 \\
\hline & O16.2.6 & 10.83 \\
\hline & O16.3.11 & 9.67 \\
\hline & O16.4.12 & 15 \\
\hline & O16.5.13 & 20.5 \\
\hline \multirow[t]{3}{*}{ J17 } & O17.1.4 & 15.08 \\
\hline & O17.2.6 & 9.83 \\
\hline & O17.3.3 & 5.33 \\
\hline \multirow[t]{2}{*}{ J18 } & O18.1.1 & 3 \\
\hline & O18.2.5 & 24.67 \\
\hline \multirow[t]{2}{*}{ J19 } & O19.1.1 & 3 \\
\hline & O19.2.5 & 24.5 \\
\hline \multirow[t]{3}{*}{ J20 } & O20.1.7 & 20 \\
\hline & O20.2.12 & 15 \\
\hline & O20.3.13 & 20.33 \\
\hline \multirow[t]{3}{*}{ J21 } & O21.1.1 & 1 \\
\hline & O21.2.6 & 5.08 \\
\hline & O21.3.3 & 1.5 \\
\hline \multirow[t]{2}{*}{ J22 } & O22.1.1 & 3 \\
\hline & O22.2.5 & 14.83 \\
\hline
\end{tabular}


O10.6.13 $\quad 112.83$

\subsection{Jadwal Awal Perusahaan}

Data jadwal yang diambil adalah jadwal pada bulan Maret 2016 untuk spare part SH28R. Notasi yang digunakan pada penelitian ini adalah notasi triplet yang digunakan pada tiap blok (i, j, k), dengan i menunjukkan nomor job, j menyatakan urutan proses, dan $\mathrm{k}$ mewakili mesin yang diperlukan. Jadwal tersebut dapat dilihat pada Tabel 4.

Tabel 4 Jadwal Perusahaan dengan aturan random

\begin{tabular}{|c|c|}
\hline Order & Urutan \\
\hline 4 Maret & $\begin{array}{l}\mathrm{O} 10.1 .15-\mathrm{O} 3.1 .1-\mathrm{O} 1.1 .2-\mathrm{O} 4.1 .1-\mathrm{O} 21.1 .1-\mathrm{O} 3.2 .8-\mathrm{O} 4.2 .5-\mathrm{O} 11.1 .4-\mathrm{O} 1.2 .8- \\
\mathrm{O} 21.2 .6-\mathrm{O} 3.3 .9-\mathrm{O} 16.1 .1-\mathrm{O} 2.1 .2-\mathrm{O} 21.3 .3-\mathrm{O} 11.2 .3-\mathrm{O} 3.4 .7-\mathrm{O} 4.3 .8-\mathrm{O} 10.2 .16- \\
\mathrm{O} 15.1 .15-\mathrm{O} 2.2 .8-\mathrm{O} 18.1 .1-\mathrm{O} 17.1 .4-\mathrm{O} 16.2 .6-\mathrm{O} 11.3 .6-\mathrm{O} 3.5 .12-\mathrm{O} 2.3 .12-\mathrm{O} 10.3 .3 \\
-\mathrm{O} 15.2 .6-\mathrm{O} 9.1 .15-\mathrm{O} 18.2 .5-\mathrm{O} 17.2 .6-\mathrm{O} 2.4 .13-\mathrm{O} 3.6 .14-\mathrm{O} 7.1 .1-\mathrm{O} 8.1 .15-\mathrm{O} 9.2 .6- \\
\mathrm{O} 6.1 .2-\mathrm{O} 10.4 .11-\mathrm{O} 7.2 .5-\mathrm{O} 12.1 .1-\mathrm{O} 15.3 .3-\mathrm{O} 8.2 .6-\mathrm{O} 6.2 .8-\mathrm{O} 5.1 .2-\mathrm{O} 10.5 .12- \\
\mathrm{O} 11.4 .10-\mathrm{O} 12.2 .5-\mathrm{O} 15.4 .12-\mathrm{O} 22.1 .1-\mathrm{O} 20.1 .7-\mathrm{O} 7.3 .7-\mathrm{O} 5.2 .8-\mathrm{O} 9.3 .12-\mathrm{O} 8.3 .12 \\
-\mathrm{O} 9.4 .13-\mathrm{O} 13.1 .1-\mathrm{O} 10.6 .13-\mathrm{O} 7.4 .12-\mathrm{O} 19.1 .1-\mathrm{O} 22.2 .5-\mathrm{O} 13.2 .5-\mathrm{O} 15.5 .13- \\
\mathrm{O} 19.2 .5-\mathrm{O} 8.4 .13-\mathrm{O} 14.1 .1-\mathrm{O} 16.3 .11-\mathrm{O} 17.3 .3-\mathrm{O} 20.2 .12-\mathrm{O} 7.5 .14-\mathrm{O} 16.4 .12- \\
\mathrm{O} 14.2 .5-\mathrm{O} 16.5 .13-\mathrm{O} 20.3 .13\end{array}$ \\
\hline 11 Maret & $\begin{array}{l}\mathrm{O} 10.1 .15-\mathrm{O} 1.1 .2-\mathrm{O} 7.1 .1-\mathrm{O} 3.1 .1-\mathrm{O} 1.2 .8-\mathrm{O} 15.1 .2-\mathrm{O} 7.2 .5-\mathrm{O} 3.2 .8-\mathrm{O} 16.1 .1- \\
\mathrm{O} 4.1 .1-\mathrm{O} 15.2 .6-\mathrm{O} 11.1 .4-\mathrm{O} 3.3 .9-\mathrm{O} 10.2 .16-\mathrm{O} 8.1 .15-\mathrm{O} 11.2 .3-\mathrm{O} 13.1 .1-\mathrm{O} 4.2 .5- \\
\mathrm{O} 17.1 .4-\mathrm{O} 16.2 .6-\mathrm{O} 10.3 .3-\mathrm{O} 19.1 .1-\mathrm{O} 15.3 .3-\mathrm{O} 8.2 .6-\mathrm{O} 9.1 .15-\mathrm{O} 3.4 .7-\mathrm{O} 4.3 .8- \\
\mathrm{O} 11.3 .6-\mathrm{O} 15.4 .12-\mathrm{O} 10.4 .11-\mathrm{O} 2.1 .2-\mathrm{O} 15.5 .13-\mathrm{O} 8.3 .12-\mathrm{O} 9.2 .6-\mathrm{O} 19.2 .5- \\
\mathrm{O} 10.5 .12-\mathrm{O} 17.2 .6-\mathrm{O} 2.2 .8-\mathrm{O} 21.1 .1-\mathrm{O} 3.5 .12-\mathrm{O} 7.3 .7-\mathrm{O} 11.4 .10-\mathrm{O} 10.6 .13-\mathrm{O} 8.4 .13 \\
-\mathrm{O} 17.3 .3-\mathrm{O} 22.1 .1-\mathrm{O} 9.3 .12-\mathrm{O} 3.6 .14-\mathrm{O} 21.2 .6-\mathrm{O} 2.3 .12-\mathrm{O} 5.1 .2-\mathrm{O} 7.4 .12-\mathrm{O} 12.1 .1- \\
\mathrm{O} 22.2 .5-\mathrm{O} 16.3 .11-\mathrm{O} 18.1 .1-\mathrm{O} 9.4 .13-\mathrm{O} 5.2 .8-\mathrm{O} 6.1 .2-\mathrm{O} 21.3 .3-\mathrm{O} 7.5 .14-\mathrm{O} 20.1 .7- \\
\mathrm{O} 12.2 .5-\mathrm{O} 13.2 .5-\mathrm{O} 14.1 .1-\mathrm{O} 2.4 .13-\mathrm{O} 16.4 .12-\mathrm{O} 6.2 .8-\mathrm{O} 20.2 .12-\mathrm{O} 18.2 .5- \\
\mathrm{O} 16.5 .13-\mathrm{O} 14.2 .5-\mathrm{O} 20.3 .13\end{array}$ \\
\hline $\begin{array}{l}18 \text { Maret } \\
18 \text { Maret }\end{array}$ & $\begin{array}{l}\mathrm{O} 10.1 .15-\mathrm{O} 3.1 .1-\mathrm{O} 1.1 .2-\mathrm{O} 7.1 .1-\mathrm{O} 1.2 .8-\mathrm{O} 3.2 .8-\mathrm{O} 15.1 .2-\mathrm{O} 11.1 .4-\mathrm{O} 7.2 .5- \\
\mathrm{O} 16.1 .1-\mathrm{O} 3.3 .9-\mathrm{O} 4.1 .1-\mathrm{O} 15.2 .6-\mathrm{O} 10.2 .16-\mathrm{O} 11.2 .3-\mathrm{O} 3.4 .7-\mathrm{O} 8.1 .15-\mathrm{O} 13.1 .1- \\
\mathrm{O} 4.2 .5-\mathrm{O} 17.1 .4-\mathrm{O} 16.2 .6-\mathrm{O} 10.3 .3-\mathrm{O} 19.1 .1-\mathrm{O} 11.3 .6-\mathrm{O} 3.5 .12-\mathrm{O} 15.3 .3-\mathrm{O} 8.2 .6- \\
\mathrm{O} 4.3 .8-\mathrm{O} 9.1 .15-\mathrm{O} 15.4 .12-\mathrm{O} 10.4 .11-\mathrm{O} 2.1 .2-\mathrm{O} 3.6 .14-\mathrm{O} 10.5 .13-\mathrm{O} 8.3 .12-\mathrm{O} 9.2 .6- \\
\mathrm{O} 19.2 .5-\mathrm{O} 10.6 .12-\mathrm{O} 17.2 .6-\mathrm{O} 2.2 .8-\mathrm{O} 21.1 .1-\mathrm{O} 7.3 .7-\mathrm{O} 8.4 .13-\mathrm{O} 15.5 .13-\mathrm{O} 17.3 .3- \\
\mathrm{O} 11.4 .10-\mathrm{O} 22.1 .1-\mathrm{O} 21.2 .6-\mathrm{O} 20.1 .7-\mathrm{O} 2.3 .12-\mathrm{O} 5.1 .2-\mathrm{O} 7.4 .12-\mathrm{O} 9.3 .12-\mathrm{O} 12.1 .1- \\
\mathrm{O} 22.2 .5-\mathrm{O} 16.3 .11-\mathrm{O} 18.1 .1-\mathrm{O} 5.2 .8-\mathrm{O} 6.1 .2-\mathrm{O} 21.3 .3-\mathrm{O} 7.5 .14-\mathrm{O} 2.4 .13-\mathrm{O} 12.2 .5- \\
\mathrm{O} 13.2 .5-\mathrm{O} 14.1 .1-\mathrm{O} 9.4 .13-\mathrm{O} 16.4 .12-\mathrm{O} 20.2 .12-\mathrm{O} 6.2 .8-\mathrm{O} 18.2 .5-\mathrm{O} 20.3 .13- \\
\mathrm{O} 16.5 .13-\mathrm{O} 14.2 .5 .\end{array}$ \\
\hline
\end{tabular}

Keseluruhan jadwal dari perusahaan tersebut menghasilkan makespan sebesar 7059,99 menit.

\subsection{Penjadwalan dengan Algoritma AIS}

Proses penjadwalan pertama dilakukan untuk order 4 Maret. Itu dikarenakan order tersebut datang pertama, langk-langkah penjadwalan dengan Algoritma AIS adalah sebagai berikut:

1. Inisialisasi acak dari populasi antibodi

Pada proses dilakukan pembuatan rangkaian awal yang diambil dari jadwal perusahaan yang sudah didapatkan dengan makespan 3045,68 menit (50,76 jam).

2. Representasi antibodi dan klasifikasi gen 
Pada proses ini rantai ringan ditunjukkan oleh mesin yang berada pada akhir suatu pekerjaan. Hasil penentuan jenis rantai dapat dilihat pada Tabel 5 .

Tabel 5 Penentuan Jenis Rantai (Order 4 Maret)

\begin{tabular}{|c|c|c|c|c|c|c|c|c|c|}
\hline No & Antibodi & Mesin & Waktu & Rantai & No & Antibodi & Mesin & Waktu & Ranta \\
\hline 1 & O10.1.15 & 15 & 840 & $\mathrm{H}$ & 38 & O10.4.11 & 11 & 970,5 & $\mathrm{H}$ \\
\hline 2 & O3.1.1 & 1 & 15,68 & $\mathrm{H}$ & 39 & O7.2.5 & 5 & 241,36 & $\mathrm{H}$ \\
\hline 3 & O1.1.2 & 2 & 160 & $\mathrm{H}$ & 40 & O12.1.1 & 1 & 42 & $\mathrm{H}$ \\
\hline 4 & O4.1.1 & 1 & 11,32 & $\mathrm{H}$ & 41 & O15.3.3 & 3 & 60 & $\mathrm{H}$ \\
\hline 5 & O21.1.1 & 1 & 8 & $\mathrm{H}$ & 42 & O8.2.6 & 6 & 122,68 & $\mathrm{H}$ \\
\hline 6 & O3.2.8 & 8 & 140 & $\mathrm{H}$ & 43 & O6.2.8 & 8 & 40 & $\mathrm{~L}$ \\
\hline 7 & $\mathrm{O} 4.2 .5$ & 5 & 58,68 & $\mathrm{H}$ & 44 & O5.1.2 & 2 & 60 & $\mathrm{H}$ \\
\hline 8 & O11.1.4 & 4 & 99,34 & $\mathrm{H}$ & 45 & O10.5.12 & 12 & 71 & $\mathrm{H}$ \\
\hline 9 & O1.2.8 & 8 & 240 & $\mathrm{~L}$ & 46 & O11.4.10 & 10 & 90,66 & $\mathrm{~L}$ \\
\hline 10 & O21.2.6 & 6 & 40,64 & $\mathrm{H}$ & 47 & O12.2.5 & 5 & 416,78 & $\mathrm{~L}$ \\
\hline 11 & O3.3.9 & 9 & 100 & $\mathrm{H}$ & 48 & O15.4.12 & 12 & 122 & $\mathrm{H}$ \\
\hline 12 & O16.1.1 & 1 & 21,34 & $\mathrm{H}$ & 49 & O22.1.1 & 1 & 6 & $\mathrm{H}$ \\
\hline 13 & $\mathrm{O} 2.1 .2$ & 2 & 100 & $\mathrm{H}$ & 50 & O20.1.7 & 7 & 40 & $\mathrm{H}$ \\
\hline 14 & O21.3.3 & 3 & 12 & $\mathrm{~L}$ & 51 & O7.3.7 & 7 & 360 & $\mathrm{H}$ \\
\hline 15 & O11.2.3 & 3 & 10 & $\mathrm{H}$ & 52 & O5.2.8 & 8 & 100 & $\mathrm{~L}$ \\
\hline 16 & O3.4.7 & 7 & 200 & $\mathrm{H}$ & 53 & O9.3.12 & 12 & 30 & $\mathrm{H}$ \\
\hline 17 & O4.3.8 & 8 & 40 & $\mathrm{~L}$ & 54 & O8.3.12 & 12 & 120 & $\mathrm{H}$ \\
\hline 18 & O10.2.16 & 16 & 376,5 & $\mathrm{H}$ & 55 & O9.4.13 & 13 & 39,34 & $\mathrm{~L}$ \\
\hline 19 & O15.1.15 & 15 & 380 & $\mathrm{H}$ & 56 & O13.1.1 & 1 & 8 & $\mathrm{H}$ \\
\hline 20 & $\mathrm{O} 2.2 .8$ & 8 & 40 & $\mathrm{H}$ & 57 & O10.6.13 & 13 & 225,66 & $\mathrm{~L}$ \\
\hline 21 & O18.1.1 & 1 & 6 & $\mathrm{H}$ & 58 & O7.4.12 & 12 & 121,68 & $\mathrm{H}$ \\
\hline 22 & O17.1.4 & 4 & 60,32 & $\mathrm{H}$ & 59 & O19.1.1 & 1 & 6 & $\mathrm{H}$ \\
\hline 23 & O16.2.6 & 6 & 21,66 & $\mathrm{H}$ & 60 & O22.2.5 & 5 & 29,66 & $\mathrm{~L}$ \\
\hline 24 & O11.3.6 & 6 & 41 & $\mathrm{H}$ & 61 & O13.2.5 & 5 & 60,66 & $\mathrm{~L}$ \\
\hline 25 & O3.5.12 & 12 & 61 & $\mathrm{H}$ & 62 & O15.5.13 & 13 & 159,68 & $\mathrm{~L}$ \\
\hline 26 & O2.3.12 & 12 & 50,32 & $\mathrm{H}$ & 63 & O19.2.5 & 5 & 49 & $\mathrm{~L}$ \\
\hline 27 & O10.3.3 & 3 & 49,34 & $\mathrm{H}$ & 64 & O8.4.13 & 13 & 80 & $\mathrm{~L}$ \\
\hline 28 & O15.2.6 & 6 & 117 & $\mathrm{H}$ & 65 & O14.1.1 & 1 & 42 & $\mathrm{H}$ \\
\hline 29 & O9.1.15 & 15 & 40 & $\mathrm{H}$ & 66 & O16.3.11 & 11 & 19,34 & $\mathrm{H}$ \\
\hline 30 & O18.2.5 & 5 & 49,34 & $\mathrm{~L}$ & 67 & O17.3.3 & 3 & 21,32 & $\mathrm{~L}$ \\
\hline 31 & O17.2.6 & 6 & 39,32 & $\mathrm{H}$ & 68 & O20.2.12 & 12 & 30 & $\mathrm{H}$ \\
\hline 32 & O2.4.13 & 13 & 84 & $\mathrm{~L}$ & 69 & O7.5.14 & 14 & 240 & $\mathrm{~L}$ \\
\hline 33 & O3.6.14 & 14 & 120 & $\mathrm{~L}$ & 70 & O16.4.12 & 12 & 30 & $\mathrm{H}$ \\
\hline 34 & O7.1.1 & 1 & 120,64 & $\mathrm{H}$ & 71 & O14.2.5 & 5 & 280,98 & $\mathrm{~L}$ \\
\hline 35 & O8.1.15 & 15 & 160 & $\mathrm{H}$ & 72 & O16.5.13 & 13 & 41 & $\mathrm{~L}$ \\
\hline 36 & O9.2.6 & 6 & 31,66 & $\mathrm{H}$ & 73 & O20.3.13 & 13 & 40,66 & $\mathrm{~L}$ \\
\hline 37 & O6.1.2 & 2 & 20 & $\mathrm{H}$ & & & & & \\
\hline
\end{tabular}

\section{Pengembangbiakan clone}

Pada tahap ini dilakukan pembuatan rangkaian baru dengan mengurutkan semua job Hasil dari pembuatan rangkaian baru tersebut dapat dilihat pada Tabel 6 .

\section{Seleksi untuk antibodi-antibodi donor}

Pada tahap ini penggantian tidak boleh mendahului proses sebelumnya pada job tersebut. Tanda panah dengan angka 1 menunjukkan penukaran antara O1.2.8 dari 
benih yang digantikan dengan $\mathrm{O} 4.3 .8$ dari donor, begitu juga seterusnya. Contoh dari penggantian rantai tersebut dapat dilihat pada Tabel 7.

Tabel 6 Rangkaian Pendonor (Order 4 Maret)

\begin{tabular}{|c|c|c|c|c|c|c|c|}
\hline No & Donor & Mesin & Rantai & No & Donor & Mesin & Rantai \\
\hline 1 & O1.1.2 & 2 & $\mathrm{H}$ & 38 & O10.6.13 & 13 & $\mathrm{~L}$ \\
\hline 2 & O1.2.8 & 8 & $\mathrm{~L}$ & 39 & O11.1.4 & 4 & $\mathrm{H}$ \\
\hline 3 & $\mathrm{O} 2.1 .2$ & 2 & $\mathrm{H}$ & 40 & O11.2.3 & 3 & $\mathrm{H}$ \\
\hline 4 & $\mathrm{O} 2.2 .8$ & 8 & $\mathrm{H}$ & 41 & O11.3.6 & 6 & $\mathrm{H}$ \\
\hline 5 & $\mathrm{O} 2.3 .12$ & 12 & $\mathrm{H}$ & 42 & O11.4.10 & 10 & $\mathrm{~L}$ \\
\hline 6 & O2.4.13 & 3 & $\mathrm{~L}$ & 43 & O12.1.1 & 1 & $\mathrm{H}$ \\
\hline 7 & O3.1.1 & 1 & $\mathrm{H}$ & 44 & O12.2.5 & 5 & $\mathrm{~L}$ \\
\hline 8 & O3.2.8 & 8 & $\mathrm{H}$ & 60 & O17.2.6 & 6 & $\mathrm{H}$ \\
\hline 9 & O3.3.9 & 9 & $\mathrm{H}$ & 61 & O17.3.3 & 3 & $\mathrm{~L}$ \\
\hline 10 & O3.4.7 & 7 & $\mathrm{H}$ & 62 & O18.1.1 & 1 & $\mathrm{H}$ \\
\hline 11 & O3.5.12 & 12 & $\mathrm{H}$ & 63 & O18.2.5 & 5 & $\mathrm{~L}$ \\
\hline 12 & O3.6.14 & 14 & $\mathrm{~L}$ & 64 & O19.1.1 & 1 & $\mathrm{H}$ \\
\hline 13 & O4.1.1 & 1 & $\mathrm{H}$ & 65 & O19.2.5 & 5 & $\mathrm{~L}$ \\
\hline 14 & O4.2.5 & 5 & $\mathrm{H}$ & 66 & O20.1.7 & 7 & $\mathrm{H}$ \\
\hline 15 & O4.3.8 & 8 & $\mathrm{~L}$ & 67 & O20.2.12 & 12 & $\mathrm{H}$ \\
\hline 16 & O5.1.2 & 2 & $\mathrm{H}$ & 68 & O20.3.13 & 13 & $\mathrm{~L}$ \\
\hline 17 & O5.2.8 & 8 & $\mathrm{~L}$ & 69 & O21.1.1 & 1 & $\mathrm{H}$ \\
\hline 18 & O6.1.2 & 2 & $\mathrm{H}$ & 70 & $\mathrm{O} 21.2 .6$ & 6 & $\mathrm{H}$ \\
\hline 19 & O6.2.8 & 8 & $\mathrm{~L}$ & 71 & O21.3.3 & 3 & $\mathrm{~L}$ \\
\hline 20 & O7.1.1 & 1 & $\mathrm{H}$ & 72 & O22.1.1 & 1 & $\mathrm{H}$ \\
\hline 21 & O7.2.5 & 5 & $\mathrm{H}$ & 73 & $\mathrm{O} 22.2 .5$ & 5 & $\mathrm{~L}$ \\
\hline 22 & O7.3.7 & 7 & $\mathrm{H}$ & 45 & O13.1.1 & 1 & $\mathrm{H}$ \\
\hline 23 & O7.4.12 & 12 & $\mathrm{H}$ & 46 & O13.2.5 & 5 & $\mathrm{~L}$ \\
\hline 24 & O7.5.14 & 14 & $\mathrm{~L}$ & 47 & O14.1.1 & 1 & $\mathrm{H}$ \\
\hline 25 & O8.1.15 & 15 & $\mathrm{H}$ & 48 & O14.2.5 & 5 & $\mathrm{~L}$ \\
\hline 26 & O8.2.6 & 6 & $\mathrm{H}$ & 49 & O15.1.15 & 15 & $\mathrm{H}$ \\
\hline 27 & 08.3.12 & 12 & $\mathrm{H}$ & 50 & O15.2.6 & 6 & $\mathrm{H}$ \\
\hline 28 & O8.4.13 & 13 & $\mathrm{~L}$ & 51 & O15.3.3 & 3 & $\mathrm{H}$ \\
\hline 29 & O9.1.15 & 15 & $\mathrm{H}$ & 52 & O15.4.12 & 12 & $\mathrm{H}$ \\
\hline 30 & O9.2.6 & 6 & $\mathrm{H}$ & 53 & O15.5.13 & 13 & $\mathrm{~L}$ \\
\hline 31 & 09.3.12 & 12 & $\mathrm{H}$ & 54 & O16.1.1 & 1 & $\mathrm{H}$ \\
\hline 32 & O9.4.13 & 13 & $\mathrm{~L}$ & 55 & O16.2.6 & 6 & $\mathrm{H}$ \\
\hline 33 & O10.1.15 & 15 & $\mathrm{H}$ & 56 & O16.3.11 & 11 & $\mathrm{H}$ \\
\hline 34 & O10.2.16 & 16 & $\mathrm{H}$ & 57 & O16.4.12 & 12 & $\mathrm{H}$ \\
\hline 35 & O10.3.3 & 3 & $\mathrm{H}$ & 58 & O16.5.13 & 13 & $\mathrm{~L}$ \\
\hline 36 & O10.4.11 & 11 & $\mathrm{H}$ & 59 & O17.1.4 & 4 & $\mathrm{H}$ \\
\hline 37 & O10.5.12 & 12 & $\mathrm{H}$ & & & & \\
\hline
\end{tabular}

\section{Konstruksi germ-line}

Pada tahap ini dilakukan pembentukan garis yang dianggap memenuhi asumsi dari perhitungan job yang ada. Sebagai asumsi diambil perbaikan pada job yang mengalami penggunaan mesin terbanyak, yaitu mesin 13. Sehingga rangkaian baru yang dihasilkan dapat dilihat pada Tabel 8. 
Tabel 7 Contoh Pencarian Antibodi untuk Perbaikan Benih (Order 4 Maret)

\begin{tabular}{|c|c|c|c|c|c|c|c|c|c|c|}
\hline Benih & Mesin & Rantai & & & Donor & Mesin & Rantai & Antibodi & Mesin & Rantai \\
\hline O10.1.15 & 15 & $\mathrm{H}$ & & & O1.1.2 & 2 & $\mathrm{H}$ & O10.1.15 & 15 & $\mathrm{H}$ \\
\hline O3.1.1 & 1 & $\mathrm{H}$ & & 3 & O1.2.8 & 8 & $\mathrm{~L}$ & O3.1.1 & 1 & $\mathrm{H}$ \\
\hline O1.1.2 & 2 & $\mathrm{H}$ & & & $\mathrm{O} 2.1 .2$ & 2 & $\mathrm{H}$ & O1.1.2 & 2 & $\mathrm{H}$ \\
\hline O4.1.1 & 1 & $\mathrm{H}$ & & & $\mathrm{O} 2.2 .8$ & 8 & $\mathrm{H}$ & O4.1.1 & 1 & $\mathrm{H}$ \\
\hline O21.1.1 & 1 & $\mathrm{H}$ & & & O2.3.12 & 12 & $\mathrm{H}$ & O21.1.1 & 1 & $\mathrm{H}$ \\
\hline O3.2.8 & 8 & $\mathrm{H}$ & & 5 & $\mathrm{O} 2.4 .13$ & 13 & $\mathrm{~L}$ & O3.2.8 & 8 & $\mathrm{H}$ \\
\hline $\mathrm{O} 4.2 .5$ & 5 & $\mathrm{H}$ & & & O3.1.1 & 1 & $\mathrm{H}$ & O4.2.5 & 5 & $\mathrm{H}$ \\
\hline O11.1.4 & 4 & $\mathrm{H}$ & & & O3.2.8 & 8 & $\mathrm{H}$ & O11.1.4 & 4 & $\mathrm{H}$ \\
\hline 01.2 .8 & 8 & $\mathrm{~L}$ & 41 & & O3.3.9 & 9 & $\mathrm{H}$ & O4.3.8 & 8 & $\mathrm{H}$ \\
\hline $\mathrm{O} 21.2 .6$ & 6 & $\mathrm{H}$ & & & O3.4.7 & 7 & $\mathrm{H}$ & $\mathrm{O} 21.2 .6$ & 6 & $\mathrm{H}$ \\
\hline O3.3.9 & 9 & $\mathrm{H}$ & & & O3.5.12 & 12 & $\mathrm{H}$ & O3.3.9 & 9 & $\mathrm{H}$ \\
\hline O16.1.1 & 1 & $\mathrm{H}$ & & $6>$ & O3.6.14 & 14 & $\mathrm{~L}$ & O16.1.1 & 1 & $\mathrm{H}$ \\
\hline $\mathrm{O} 2.1 .2$ & 2 & $\mathrm{H}$ & & & O4.1.1 & 1 & $\mathrm{H}$ & O2.1.2 & 2 & $\mathrm{H}$ \\
\hline O21.3.3 & 3 & $\mathrm{~L}$ & 42 & & $\mathrm{O} 4.2 .5$ & 5 & $\mathrm{H}$ & O21.3.3 & 3 & $\mathrm{H}$ \\
\hline O11.2.3 & 3 & $\mathrm{H}$ & & $1>$ & O4.3.8 & 8 & $\mathrm{~L}$ & O11.2.3 & 3 & $\mathrm{H}$ \\
\hline
\end{tabular}

Tabel 8 Konstruksi Germ-line yang Baru (Order 4 Maret)

\begin{tabular}{|c|c|c|c|c|c|c|c|}
\hline No & Antibodi & Mesin & Rantai & No & Antibodi & Mesin & Rantaj \\
\hline 1 & O10.1.15 & 15 & $\mathrm{H}$ & 38 & O10.4.11 & 11 & $\mathrm{H}$ \\
\hline 2 & O3.1.1 & 1 & $\mathrm{H}$ & 39 & O7.2.5 & 5 & $\mathrm{H}$ \\
\hline 3 & O1.1.2 & 2 & $\mathrm{H}$ & 40 & O12.1.1 & 1 & $\mathrm{H}$ \\
\hline 4 & O4.1.1 & 1 & $\mathrm{H}$ & 41 & O15.3.3 & 3 & $\mathrm{H}$ \\
\hline 5 & O21.1.1 & 1 & $\mathrm{H}$ & 42 & O8.2.6 & 6 & $\mathrm{H}$ \\
\hline 6 & O3.2.8 & 8 & $\mathrm{H}$ & 43 & O6.2.8 & 8 & $\mathrm{~L}$ \\
\hline 7 & O4.2.5 & 5 & $\mathrm{H}$ & 44 & O5.1.2 & 2 & $\mathrm{H}$ \\
\hline 8 & O11.1.4 & 4 & $\mathrm{H}$ & 45 & O10.5.12 & 12 & $\mathrm{H}$ \\
\hline 9 & O1.2.8 & 8 & $\mathrm{~L}$ & 46 & O11.4.10 & 10 & $\mathrm{~L}$ \\
\hline 10 & $\mathrm{O} 21.2 .6$ & 6 & $\mathrm{H}$ & 47 & O12.2.5 & 5 & $\mathrm{~L}$ \\
\hline 11 & O3.3.9 & 9 & $\mathrm{H}$ & 48 & O15.4.12 & 12 & $\mathrm{H}$ \\
\hline 12 & O16.1.1 & 1 & $\mathrm{H}$ & 49 & O22.1.1 & 1 & $\mathrm{H}$ \\
\hline 13 & $\mathrm{O} 2.1 .2$ & 2 & $\mathrm{H}$ & 50 & O20.1.7 & 7 & $\mathrm{H}$ \\
\hline 14 & O21.3.3 & 3 & $\mathrm{~L}$ & 51 & O7.3.7 & 7 & $\mathrm{H}$ \\
\hline 15 & O11.2.3 & 3 & $\mathrm{H}$ & 52 & O5.2.8 & 8 & $\mathrm{~L}$ \\
\hline 16 & O3.4.7 & 7 & $\mathrm{H}$ & 53 & O9.3.12 & 12 & $\mathrm{H}$ \\
\hline 17 & O4.3.8 & 8 & $\mathrm{~L}$ & 54 & O8.3.12 & 12 & $\mathrm{H}$ \\
\hline 18 & O10.2.16 & 16 & $\mathrm{H}$ & 55 & O10.6.13 & 13 & $\mathrm{H}$ \\
\hline 19 & O15.1.15 & 15 & $\mathrm{H}$ & 56 & O13.1.1 & 1 & $\mathrm{H}$ \\
\hline 20 & O2.2.8 & 8 & $\mathrm{H}$ & 57 & O15.5.13 & 13 & $\mathrm{H}$ \\
\hline 21 & O18.1.1 & 1 & $\mathrm{H}$ & 58 & O7.4.12 & 12 & $\mathrm{H}$ \\
\hline 22 & O17.1.4 & 4 & $\mathrm{H}$ & 59 & O19.1.1 & 1 & $\mathrm{H}$ \\
\hline 23 & O16.2.6 & 6 & $\mathrm{H}$ & 60 & $\mathrm{O} 22.2 .5$ & 5 & $\mathrm{~L}$ \\
\hline 24 & O11.3.6 & 6 & $\mathrm{H}$ & 61 & O13.2.5 & 5 & $\overline{\mathrm{L}}$ \\
\hline 25 & O3.5.12 & 12 & $\mathrm{H}$ & 62 & O9.4.13 & 13 & $\mathrm{H}$ \\
\hline 26 & O2.3.12 & 12 & $\mathrm{H}$ & 63 & O19.2.5 & 5 & $\mathrm{~L}$ \\
\hline 27 & O10.3.3 & 3 & $\mathrm{H}$ & 64 & O8.4.13 & 13 & $\mathrm{~L}$ \\
\hline 28 & O15.2.6 & 6 & $\mathrm{H}$ & 65 & O14.1.1 & 1 & $\mathrm{H}$ \\
\hline 29 & O9.1.15 & 15 & $\mathrm{H}$ & 66 & O16.3.11 & 11 & $\mathrm{H}$ \\
\hline 30 & O18.2.5 & 5 & $\mathrm{~L}$ & 67 & O17.3.3 & 3 & $\mathrm{~L}$ \\
\hline 31 & O17.2.6 & 6 & $\mathrm{H}$ & 68 & O20.2.12 & 12 & $\mathrm{H}$ \\
\hline 32 & $\mathrm{O} 2.4 .13$ & 13 & $\mathrm{~L}$ & 69 & O7.5.14 & 14 & $\mathrm{~L}$ \\
\hline 33 & O3.6.14 & 14 & $\mathrm{~L}$ & 70 & O16.4.12 & 12 & $\mathrm{H}$ \\
\hline 34 & O7.1.1 & 1 & $\mathrm{H}$ & 71 & O14.2.5 & 5 & $\mathrm{~L}$ \\
\hline 35 & O8.1.15 & 15 & $\mathrm{H}$ & 72 & O20.3.13 & 13 & $\mathrm{H}$ \\
\hline 36 & O9.2.6 & 6 & $\mathrm{H}$ & 73 & O16.5.13 & 13 & $\mathrm{H}$ \\
\hline 37 & O6.1.2 & 2 & $\mathrm{H}$ & & & & \\
\hline
\end{tabular}




\section{Pengaturan ulang fragmen gen}

Pengaturan ulang gen tidak dilakukan, karena perbaikan pada penjadwalan mesin 13 sudah meminimalisasi dari makespan sebelumnya yaitu 2941,02 menit (49,02 jam).

\section{Diversifikasi antibody}

- Mutasi titik somatis

Pada proses ini dilakukan pengaturan dengan mesin yang memiliki waktu proses terlama dilakukan pada akhir proses produksi. Didapatkan dari pengamatan bahwa job 10 (970,5 menit) memiliki waktu proses terlama, tetapi mekanisme tersebut menghasilkan makespan yang lebih besar dari rangkaian awal, begitu juga dengan waktu proses kedua terlama. Sehingga waktu proses ketiga yang paling lama adalah job 15 (380 menit) yang terpilih karena menghasilkan makespan yang lebih kecil dari rangkaian awal. Contoh dari proses mutasi titik somatis dapat dilihat pada Tabel 9.

Tabel 9 Contoh Pencarian Antibodi Baru dengan Mutasi Titik Somatis (Order 4

\begin{tabular}{cc}
\hline Antibodi & Mesin \\
\hline O17.2.6 & 6 \\
O2.4.13 & 13 \\
O3.6.14 & 14 \\
O7.1.1 & 1 \\
O8.1.15 & 15 \\
O9.2.6 & 6 \\
O6.1.2 & 2 \\
O10.4.11 & 11 \\
O7.2.5 & 5 \\
O12.1.1 & 1 \\
O15.3.3 & 3 \\
\hline
\end{tabular}

\begin{tabular}{cccc}
\multicolumn{2}{c}{ Maret) } & & \\
\cline { 2 - 5 } Donor & Mesin & Antibodi Baru & Mesin \\
\hline O9.3.12 & 12 & O17.2.6 & 6 \\
O9.4.13 & 13 & O2.4.13 & 13 \\
O10.1.15 & 15 & O3.6.14 & 14 \\
O10.2.16 & 16 & O7.1.1 & 1 \\
O10.3.3 & 3 & O8.1.15 & 15 \\
O10.4.11 & 11 & O9.2.6 & 6 \\
O10.5.12 & 12 & O6.1.2 & 2 \\
O10.6.13 & 13 & O10.4.11 & 11 \\
O11.1.4 & 4 & O7.2.5 & 5 \\
O11.2.3 & 3 & O12.1.1 & 1 \\
O11.3.6 & 6 & O9.3.12 & 12 \\
\hline
\end{tabular}

- Rekombinasi somatis

Pada proses ini dilakukan pengaturan dengan pemilihan satu atau lebih fragmen gen rantai tebal $(\mathrm{H})$ dengan panjang yang sama. Tanda panah dengan angka 1 menunjukkan penukaran antara O10.5.12 - O11.4.10 dengan O15.1.15 - O8.3.12, begitu juga seterusnya. Contoh dari proses mutasi titik somatis dapat dilihat pada Tabel 10.

Tabel 10 Contoh Pencarian Antibodi Baru dengan Rekombinasi Somatis (Order 4

\begin{tabular}{|c|c|}
\hline Antibodi & Mesin \\
\hline O6.2.8 & 8 \\
\hline O5.1.2 & 2 \\
\hline O10.5.12 & 12 \\
\hline O11.4.10 & 10 \\
\hline O12.2.5 & 5 \\
\hline O9.4.13 & 13 \\
\hline O22.1.1 & 1 \\
\hline O20.3.13 & 13 \\
\hline O7.3.7 & 7 \\
\hline O5.2.8 & 8 \\
\hline O15.1.15 & 15 \\
\hline O8.3.12 & 12 \\
\hline O10.6.13 & 13 \\
\hline
\end{tabular}

\begin{tabular}{|c|c|c|c|c|}
\hline \multicolumn{5}{|c|}{ Maret) } \\
\hline & Antibodi & Mesin & Antibodi Baru & Mesin \\
\hline \multirow{8}{*}{$2 \\
{$} & O6.2.8 & 8 & $\mathrm{O} 6.2 .8$ & 8 \\
\hline & O5.1.2 & 2 & O5.1.2 & 2 \\
\hline & O10.5.12 & 12 & O15.1.15 & 15 \\
\hline & O11.4.10 & 10 & O8.3.12 & 12 \\
\hline & O12.2.5 & 5 & O12.2.5 & 5 \\
\hline & O9.4.13 & 13 & 09.4.13 & 13 \\
\hline & O22.1.1 & 1 & O22.1.1 & 1 \\
\hline & O20.3.13 & 13 & O20.3.13 & 13 \\
\hline \multirow{5}{*}{$1 \triangleright\{$} & O7.3.7 & 7 & O7.3.7 & 7 \\
\hline & O5.2.8 & 8 & O5.2.8 & 8 \\
\hline & O15.1.15 & 15 & O10.5.12 & 12 \\
\hline & O8.3.12 & 12 & O11.4.10 & 10 \\
\hline & O10.6.13 & 13 & O10.6.13 & 13 \\
\hline
\end{tabular}


Untuk penjadwalan order 11 dan 12 Maret sama seperti penjadwalan order 4 Maret, sehingga didapatkan jadwal untuk masing-masing order yang dapat dilihat pada Tabel 11.

Tabel 11 Jadwal Algoritma AIS

\begin{tabular}{|c|c|}
\hline Order & Urutan \\
\hline 4 Maret & $\begin{array}{l}\mathrm{O} 10.1 .15-\mathrm{O} 3.1 .1-\mathrm{O} 1.1 .2-\mathrm{O} 4.1 .1-\mathrm{O} 21.1 .1-\mathrm{O} 3.2 .8-\mathrm{O} 4.2 .5-\mathrm{O} 11.1 .4-\mathrm{O} 1.2 .8-\mathrm{O} 21.2 .6- \\
\mathrm{O} 3.3 .9-\mathrm{O} 16.1 .1-\mathrm{O} 2.1 .2-\mathrm{O} 21.3 .3-\mathrm{O} 11.2 .3-\mathrm{O} 3.4 .7-\mathrm{O} 4.3 .8-\mathrm{O} 10.2 .16-\mathrm{O} 20.1 .7-\mathrm{O} 2.2 .8- \\
\mathrm{O} 18.1 .1-\mathrm{O} 17.1 .4-\mathrm{O} 16.2 .6-\mathrm{O} 11.3 .6-\mathrm{O} 3.5 .12-\mathrm{O} 2.3 .12-\mathrm{O} 10.3 .3-\mathrm{O} 20.2 .12-\mathrm{O} 9.1 .15- \\
\mathrm{O} 18.2 .5-\mathrm{O} 17.2 .6-\mathrm{O} 2.4 .13-\mathrm{O} 3.6 .14-\mathrm{O} 7.1 .1-\mathrm{O} 8.1 .15-\mathrm{O} 9.2 .6-\mathrm{O} 6.1 .2-\mathrm{O} 10.4 .11-\mathrm{O} 7.2 .5- \\
\mathrm{O} 12.1 .1-\mathrm{O} 9.3 .12-\mathrm{O} 8.2 .6-\mathrm{O} 6.2 .8-\mathrm{O} 5.1 .2-\mathrm{O} 15.1 .15-\mathrm{O} 8.3 .12-\mathrm{O} 12.2 .5-\mathrm{O} 9.4 .13-\mathrm{O} 22.1 .1- \\
\mathrm{O} 20.3 .13-\mathrm{O} 7.3 .7-\mathrm{O} 5.2 .8-\mathrm{O} 10.5 .12-\mathrm{O} 11.4 .10-\mathrm{O} 10.6 .13-\mathrm{O} 13.1 .1-\mathrm{O} 15.2 .6-\mathrm{O} 7.4 .12- \\
\mathrm{O} 19.1 .1-\mathrm{O} 22.2 .5-\mathrm{O} 13.2 .5-\mathrm{O} 15.3 .3-\mathrm{O} 19.2 .5-\mathrm{O} 8.4 .13-\mathrm{O} 14.1 .1-\mathrm{O} 16.3 .11-\mathrm{O} 17.3 .3- \\
\mathrm{O} 15.4 .12-\mathrm{O} 7.5 .14-\mathrm{O} 16.4 .12-\mathrm{O} 14.2 .5-\mathrm{O} 15.5 .13-\mathrm{O} 16.5 .13\end{array}$ \\
\hline 11 Maret & $\begin{array}{l}\mathrm{O} 10.1 .15-\mathrm{O} 2.1 .2-\mathrm{O} 7.1 .1-\mathrm{O} 3.1 .1-\mathrm{O} 1.1 .2-\mathrm{O} 20.1 .7-\mathrm{O} 7.2 .5-\mathrm{O} 3.2 .8-\mathrm{O} 16.1 .1-\mathrm{O} 4.1 .1- \\
\mathrm{O} 20.2 .12-\mathrm{O} 11.1 .4-\mathrm{O} 3.3 .9-\mathrm{O} 10.2 .16-\mathrm{O} 8.1 .15-\mathrm{O} 11.2 .3-\mathrm{O} 13.1 .1-\mathrm{O} 4.2 .5-\mathrm{O} 17.1 .4-\mathrm{O} 7.3 .7- \\
\mathrm{O} 10.3 .3-\mathrm{O} 19.1 .1-\mathrm{O} 20.3 .13-\mathrm{O} 8.2 .6-\mathrm{O} 9.1 .15-\mathrm{O} 3.4 .7-\mathrm{O} 3.5 .12-\mathrm{O} 11.3 .6-\mathrm{O} 7.4 .12-\mathrm{O} 10.4 .11- \\
\mathrm{O} 2.2 .8-\mathrm{O} 2.3 .12-\mathrm{O} 8.3 .12-\mathrm{O} 9.2 .6-\mathrm{O} 9.3 .12-\mathrm{O} 10.5 .12-\mathrm{O} 17.2 .6-\mathrm{O} 1.2 .8-\mathrm{O} 21.1 .1-\mathrm{O} 4.3 .8- \\
\mathrm{O} 14.1 .1-\mathrm{O} 11.4 .10-\mathrm{O} 8.4 .13-\mathrm{O} 18.1 .1-\mathrm{O} 2.4 .13-\mathrm{O} 22.1 .1-\mathrm{O} 19.2 .5-\mathrm{O} 3.6 .14-\mathrm{O} 21.2 .6-\mathrm{O} 14.2 .5 \\
-\mathrm{O} 5.1 .2-\mathrm{O} 16.2 .6-\mathrm{O} 12.1 .1-\mathrm{O} 22.2 .5 \mathrm{O} 16.3 .11-\mathrm{O} 10.6 .13-\mathrm{O} 17.3 .3-\mathrm{O} 5.2 .8-\mathrm{O} 6.1 .2-\mathrm{O} 21.3 .3- \\
\mathrm{O} 7.5 .14-\mathrm{O} 15.1 .15-\mathrm{O} 12.2 .5-\mathrm{O} 13.2 .5-\mathrm{O} 15.2 .6-\mathrm{O} 9.4 .13-\mathrm{O} 16.4 .12-\mathrm{O} 6.2 .8-\mathrm{O} 15.3 .3-\mathrm{O} 18.2 .5 \\
-\mathrm{O} 15.4 .12-\mathrm{O} 15.5 .13-\mathrm{O} 16.5 .13\end{array}$ \\
\hline 18 Maret & $\begin{array}{l}\mathrm{O} 10.1 .15-\mathrm{O} 3.1 .1-\mathrm{O} 1.1 .2-\mathrm{O} 7.1 .1-\mathrm{O} 1.2 .8-\mathrm{O} 3.2 .8-\mathrm{O} 15.1 .15-\mathrm{O} 11.1 .4-\mathrm{O} 7.2 .5-\mathrm{O} 16.1 .1- \\
\mathrm{O} 3.3 .9-\mathrm{O} 4.1 .1-\mathrm{O} 15.2 .6-\mathrm{O} 10.2 .16-\mathrm{O} 11.2 .3-\mathrm{O} 3.4 .7-\mathrm{O} 8.1 .15-\mathrm{O} 13.1 .1-\mathrm{O} 4.2 .5-\mathrm{O} 17.1 .4- \\
\mathrm{O} 16.2 .6-\mathrm{O} 10.3 .3-\mathrm{O} 19.1 .1-\mathrm{O} 11.3 .6-\mathrm{O} 3.5 .12-\mathrm{O} 15.3 .3-\mathrm{O} 8.2 .6-\mathrm{O} 4.3 .8-\mathrm{O} 9.1 .15-\mathrm{O} 15.4 .12- \\
\mathrm{O} 10.4 .11-\mathrm{O} 2.1 .2-\mathrm{O} 3.6 .14-\mathrm{O} 15.5 .13-\mathrm{O} 8.3 .12-\mathrm{O} 9.2 .6-\mathrm{O} 19.2 .5-\mathrm{O} 10.5 .12-\mathrm{O} 17.2 .6-\mathrm{O} 2.2 .8- \\
\mathrm{O} 21.1 .1-\mathrm{O} 7.3 .7-\mathrm{O} 14.1 .1-\mathrm{O} 8.4 .13-\mathrm{O} 17.3 .3-\mathrm{O} 11.4 .10-\mathrm{O} 22.1 .1-\mathrm{O} 21.2 .6-\mathrm{O} 20.1 .7-\mathrm{O} 2.3 .12- \\
\mathrm{O} 5.1 .2-\mathrm{O} 7.4 .12-\mathrm{O} 9.3 .12-\mathrm{O} 20.2 .12-\mathrm{O} 9.4 .13-\mathrm{O} 20.3 .13-\mathrm{O} 18.1 .1-\mathrm{O} 5.2 .8-\mathrm{O} 6.1 .2-\mathrm{O} 2.4 .13- \\
\mathrm{O} 7.5 .14-\mathrm{O} 22.2 .5-\mathrm{O} 16.3 .11-\mathrm{O} 13.2 .5-\mathrm{O} 10.6 .13-\mathrm{O} 21.3 .3-\mathrm{O} 16.4 .12-\mathrm{O} 12.1 .1-\mathrm{O} 6.2 .8- \\
\mathrm{O} 18.2 .5-\mathrm{O} 16.5 .13-\mathrm{O} 12.2 .5-\mathrm{O} 14.2 .5\end{array}$ \\
\hline
\end{tabular}

Keseluruhan jadwal dari algoritma AIS tersebut menghasilkan makespan 6483,91 menit.

\subsection{Waktu Keterlambatan}

Setelah penjadwalan selesai, maka selanjutnya dilakukan perhitungan waktu keterlambatan untuk mengetahui penyelesaian produk tersebut terlambat atau tidak. Lama waktu assembly untuk produk SH28R dan SH38R adalah 3 hari untuk 1 unit. Sehingga perhitungan untuk waktu keterlambatan pembuatan adalah sebagai berikut: Completion time order 1 = Tanggal bisa dimulai assembly + lama assembly + hari libur

$$
\begin{aligned}
& =17+6+2 \\
& =25 \text { Maret }
\end{aligned}
$$

Untuk menghitung latness dari jadwal dilakukan menggunakan Pers (1), untuk contoh perhitungannya sebagai berikut:

Latness order $1=25-25$

$$
=0
$$
Tabel 12

Hasil perhitungan waktu keterlambatan untuk semua jadwal dapat dilihat pada 
Tabel 12 Hasil Perhitungan Waktu Keterlambatan

\begin{tabular}{|c|c|c|c|c|c|c|}
\hline \multirow[t]{2}{*}{ Jadwal } & \multicolumn{3}{|c|}{ Perusahaan } & \multicolumn{3}{|c|}{ Algoritma AIS } \\
\hline & Order 1 & Order 2 & Order 3 & Order 1 & Order 2 & Order 3 \\
\hline $\begin{array}{l}\text { Tanggal } \\
\text { Permintaan }\end{array}$ & 4 Maret & 11 Maret & 18 Maret & 4 Maret & 11 Maret & 18 Maret \\
\hline $\begin{array}{l}\text { Due Date } \\
\text { Produk }\end{array}$ & 25 Maret & 29 Maret & 30 Maret & 25 Maret & 29 Maret & 30 Maret \\
\hline $\begin{array}{l}\text { Tanggal } \\
\text { Dimulai } \\
\text { Assembly }\end{array}$ & 17 Maret & 22 Maret & 24 Maret & 17 Maret & 21 Maret & 23 Maret \\
\hline $\begin{array}{l}\text { Lama } \\
\text { Assembly }\end{array}$ & 6 Hari & 6 Hari & 3 Hari & 6 Hari & 6 Hari & 3 Hari \\
\hline Hari Libur & 2 Hari & 2 Hari & 2 Hari & 2 Hari & 2 Hari & 0 Hari \\
\hline Lateness & 0 & 1 & -1 & 0 & 0 & -4 \\
\hline
\end{tabular}

Tabel 13 Hasil Perhitungan Total Waktu Proses

\begin{tabular}{|c|c|c|c|c|}
\hline \multicolumn{2}{|c|}{ Mesin } & $\begin{array}{c}\text { Total Waktu } \\
\text { Proses (menit) }\end{array}$ & $\begin{array}{c}\text { Utilitas } \\
\text { Perusahaan }\end{array}$ & $\begin{array}{c}\text { Utilitas } \\
\text { Algoritma AIS }\end{array}$ \\
\hline \multicolumn{2}{|c|}{ M1 } & 817,77 & 0,12 & 0,13 \\
\hline \multicolumn{2}{|c|}{ M2 } & 850 & 0,12 & 0,13 \\
\hline \multicolumn{2}{|c|}{ M3 } & 393,65 & 0,06 & 0,06 \\
\hline \multirow{2}{*}{ M4 } & 1 & 298,02 & 0,04 & 0,05 \\
\hline & 2 & 180,96 & 0,03 & 0,03 \\
\hline \multirow{6}{*}{ M5 } & 1 & 590,4 & 0,08 & 0,09 \\
\hline & 2 & 467,68 & 0,07 & 0,07 \\
\hline & 3 & 816,61 & 0,12 & 0,13 \\
\hline & 4 & 461,27 & 0,07 & 0,07 \\
\hline & 5 & 773,91 & 0,11 & 0,12 \\
\hline & 6 & 236,98 & 0,03 & 0,04 \\
\hline \multirow{4}{*}{ M6 } & 1 & 378,14 & 0,05 & 0,06 \\
\hline & 2 & 246,39 & 0,03 & 0,04 \\
\hline & 3 & 200,01 & 0,03 & 0,03 \\
\hline & 4 & 251 & 0,04 & 0,04 \\
\hline \multirow{3}{*}{ M7 } & 1 & 500 & 0,07 & 0,08 \\
\hline & 2 & 760 & 0,11 & 0,12 \\
\hline & 3 & 460 & 0,07 & 0,07 \\
\hline \multirow{6}{*}{ M8 } & 1 & 500 & 0,07 & 0,08 \\
\hline & 2 & 450 & 0,06 & 0,07 \\
\hline & 3 & 100 & 0,01 & 0,02 \\
\hline & 4 & 100 & 0,01 & 0,02 \\
\hline & 5 & 190 & 0,03 & 0,03 \\
\hline & 6 & 160 & 0,02 & 0,02 \\
\hline M9 & & 250 & 0,04 & 0,04 \\
\hline M10 & & 226,65 & 0,03 & 0,03 \\
\hline \multirow[t]{2}{*}{ M11 } & 1 & 2426,25 & 0,34 & 0,37 \\
\hline & 2 & 48,35 & 0,01 & 0,01 \\
\hline \multicolumn{2}{|l|}{ M12 } & 1680,84 & 0,24 & 0,26 \\
\hline \multicolumn{2}{|l|}{ M13 } & 1716,51 & 0,24 & 0,26 \\
\hline \multicolumn{2}{|l|}{ M14 } & 1020 & 0,14 & 0,16 \\
\hline \multicolumn{2}{|l|}{ M15 } & 3550 & 0,50 & 0,55 \\
\hline \multirow[t]{2}{*}{ M16 } & & 941,25 & 0,13 & 0,15 \\
\hline & & Rata-rata & 0,09 & 0,10 \\
\hline
\end{tabular}


Pekerjaan selesai tepat pada waktunya jika memiliki hasil latness 0 dan melebihi due date jika memiliki hasil latness positif, sedangkan negatif menandakan pekerjaan tersebut selesai sebelum due date. Seperti hasil perhitungan latness pada order 1 untuk jadwal perusahaan dengan hasil 1, menandakan bahwa produk diselesaikan satu hari setelah due date. Sedangkan pada order 1 untuk jadwal dengan algoritma AIS didapatkan hasil -4, menandakan bahwa produk diselesaikan 4 hari sebelum due date.

\subsection{Utilitas Mesin}

Dari tahap penjadwalan yang telah dilakukan, didapatkan makespan jadwal perusahaan (7059,99 menit) dan makespan jadwal algoritma AIS (6483,91 menit) yang selanjutnya digunakan untuk menghitung utilitas mesin menggunakan Pers (2). untuk contoh perhitunganya sebagai berikut:

$$
\begin{aligned}
\mathrm{U}_{1} & =\frac{817,77}{7055,8} \\
\mathrm{U}_{1} & =0,12
\end{aligned}
$$

Contoh perhitungan utilitas diambil dari mesin 1 (ban saw) untuk utilitas perusahaan. Untuk hasil dari perhitungan utilitas mesin dapat dilihat pada Tabel 13.

Semakin besar utilitas dari suatu mesin semakin bagus, itu dikarenakan jika utilitas mesin itu besar menandakan bahwa mesin tersebut semakin sibuk. Dari hasil utilitas pada Tabel 5 dapat dilihat bahwa mesin yang paling sibuk adalah order 1 dan order 3 M15 (Gas Cutting) pada algoritma AIS dengan utilitas sebesar 0,55 (55\%).

Rendahnya utilitas pada tiap mesin disebabkan proses pembuatan spare part yang melewati banyak mesin dengan waktu proses yang kecil, sehingga terjadi banyak waktu menunggu untuk proses selanjutnya yang menyebabkan waktu delay yang besar.

\section{Simpulan}

Penjadwalan menggunakan algoritma Artificial Immune System (AIS) yang dilakukan pada PT. Interpack Packaging and Processing Manufacturers diperoleh makespan yang lebih kecil yaitu sebesar 6483,91 menit, sedangkan makespan dari jadwal perusahaan yaitu sebesar 7059,99 menit. Jadwal algoritma AIS mampu menyelesaikan lebih cepat 4 hari dari due date. Jadwal algoritma AIS meningkatkan utilitas sebesar $1 \%$.

\section{Daftar notasi}

$\mathrm{Um} \quad=$ Utilitas mesin

ti $\quad=$ Waktu Proses

Fmax $=$ Maksimal keseluruhan waktu penyelesaian job yang ada

\section{Referensi}

[1] K. R. Baker and D. Trietsch, Principles of sequencing and scheduling: John Wiley \& Sons, 2013.

[2] R. W. Conway, W. L. Maxwell, and L. W. Miller, Theory of scheduling: Courier Corporation, 2003.

[3] J. E. Biegel, Pengendalian produksi suatu pendekatan kuantitatif. Jakarta: Akademika Pressindo, 1992. 
[4] M. Husen, I. Masudin, and D. M. Utama, "Penjadwalan Job Shop Statik Dengan Metode Simulated Annealing Untuk Meminimasi Waktu Makespan," Spektrum Industri, vol. 13, 2015.

[5] M. Firdaus, I. Masudin, and D. M. Utama, "Penjadwalan Flowshop Dengan Menggunakan Simulated Annealing," Spektrum Industri, vol. 13, 2015.

[6] I. Masudin, D. M. Utama, and F. Susastro, "Penjadwalan Flowshop Menggunakan Algoritma Nawaz Enscore HAM," 2014.

[7] S. Harto, A. K. Garside, and D. M. Utama, "penjadwalan produksi menggunakan algoritma jadwal non delay untuk meminimalkan makespan studi kasus di cv. Bima mebel," Spektrum Industri, vol. 14, 2016.

[8] M. Astuti, "Studi penjadwalan job shop untuk meminimalkan waktu keseluruhan menggunakan pendekatan algoritma artificial immune system," Jurnal Angkasa, vol. 5, pp. 19-28, 2013.

[9] L. N. De Castro and J. Timmis, Artificial immune systems: a new computational intelligence approach: Springer Science \& Business Media, 2002.

[10] I. Berlianty and M. Arifin, Teknik-teknik optimasi heuristik. Yogyakarta: Graha Ilmu, 2010. 